\title{
Determinants of the production and commercial values of Eucalyptus woodlot products in Wogera District, Northern Ethiopia
}

\author{
Abebe Birara Dessie ${ }^{1 *}$, Asmamaw Alemu Abtew ${ }^{2}$ and Abebe Dagnew Koye
}

\begin{abstract}
Background: Growing and planting of Eucalypts tree at a farm level in the form of woodlot has become a common practice among Ethiopian rural households. Currently, Ethiopian smallholder farmers mainly establish Eucalypts woodlot as a part of livelihood portfolio for meeting both household wood consumption and generating cash income. However, empirical evidence is lacking on the extent of households motivation in Eucalyptus woodlot production and factors influencing commercial values of its products. Consequently, this study investigated the factors influencing commercial value of Eucalyptus woodlot products in Wogera district.

Methods: Primary data were collected from 120 randomly selected Eucalyptus producer households through pretested questionnaires. Multiple linear regression analysis was employed to determine the significant variables affecting commercial values of Eucalyptus products in the study area.

Results: The result of the study revealed that different types of local Eucalyptus woodlot products such as pole, worage, mager, split wood and bundle of firewood were produced and used both for households' consumption and commercial purpose. Moreover, the OLS model result indicated that age $(p<0.1)$, wealth status $(p<0.1)$ and woodlot size of households $(p<0.01)$ positively and significantly determine the commercial value of Eucalyptus woodlot products. While, access to credit service and experience are significant but with negative influence on the commercial values of woodlot products at $5 \%$ levels of significance.

Conclusion: Generally, production and marketing of Eucalyptus wood products play a significant poverty alleviation role as a source of regular income, local medicine, firewood, fence and construction materials in turn improving the livelihoods of the rural community in Ethiopia. Based on the findings, providing capacity-building training to strength producer's credit usage on Eucalyptus Woodlot production system should be advisable. Moreover, the stakeholder should establish wood industry to enhance the income generation capacity of Eucalyptus for producers and traders. Finally, to reduce the conflict between crop producers and Eucalyptus producers, cluster planting are advisable.
\end{abstract}

Keywords: Woodlot, Multiple linear regression, Eucalyptus, Commercial value and Ethiopia

\section{Background}

Forest plantation is wide spreading economic activity in the highlands of Ethiopia mainly attributed to the degradation and limited access to the natural forests, introduction and popularization of fast growing tree species, as well as the awareness of smallholder farmers on the

\footnotetext{
*Correspondence: a.birara@yahoo.com

${ }^{1}$ Department of Agricultural Economics, College of Agriculture and Rural

Transformation, University of Gondar, P.O. Box 196, Gondar, Ethiopia

Full list of author information is available at the end of the article
}

financial returns from plantations. Forest plantations in the Amhara region exist in different forms such as (i) private, (ii) community, and (iii) state (Tadesse et al. 2015). Recent emerging approaches also involve plantation development on communal lands under Joint Forest Development (JFD) scheme (Raphael and Alemu 2016). Hence, smallholder farmers are the main actors in the plantation development and commercialization systems in the region and the country at large. Consequently, private small-scale plantations constitute by far the largest 
proportion of the plantation resources accounting more than two-third of the overall plantation area of the region (Tadesse et al. 2015). These plantations are typically monocrops of exotic tree species and managed with short rotation of 5-7 years. They are chiefly characterized by poor establishment and management practices, with low productivity and negative ecological effects (Yitaferu et al. 2013; Lemeneh and Kassa 2014; Tadesse et al. 2015).

The current trend of small-scale plantation expansions in the country also indicates the popular acceptance of forest plantations as an attractive business for smallholder farmers in the region. The economic potentials of exotic tree species have led to expansion of plantations not only on marginal lands but also conversion of crop lands to woodlots (Yitaferu et al. 2013; Lemeneh and Kassa 2014; Tadesse et al. 2015). However, coupled with the lack of proper lad use system and management of the plantations, negative environmental impacts are evidently resulted from the expansion of exotic monoculture plantations (Yitaferu et al. 2013, Tadesse et al. 2015).

Eucalyptus woodlots production at smallholders' farm level is becoming dominant activity in the highlands' farming system used both for subsistence and income generations (Kebebew and Ayele 2010). According to Mekonnen et al. (2007), Eucalyptus is the most single dominant plantation species in the country widely used contributing to the national consumption of construction poles (92\%), timber (74\%), firewood (85\%), charcoal $(40 \%)$, posts $(83 \%)$ and farm implements wood sources (91\%). Similar findings were also reported by Zerga and Berta (2016). This signifies the significance of smallholder plantation products on the livelihoods of rural households. Moreover, the market demand and commercial value of Eucalyptus products such as firewood, pole and charcoal were higher than the products of indigenous tree species like Cordia Africana. As result, most Ethiopian framers preferred, produce and sell Eucalyptus woodlot products than many other indigenous species (Oduol and Nang'ole 2012).

Despite the rapid expansion of smallholder woodlot productions various variables can influence the performance of forest plantation generally in Ethiopia and particularly in Amhara Region (Raphael and Alemu 2016) grouped as socio-economic, technical and institutional factors such as lack of extension service, poor market access, lack of cooperation, poor appropriate spacing, thinning, harvesting practice and inadequate institutional and policy support. Likewise, the main socio-economic variables that significantly determine absolute income generated from gum and resin were volume of production, experience, storage, livestock holding, land holding, household size, off-farm and agricultural income (Alemu et al. 2014). Moreover, Eucalyptus is a fast growing, relatively need low cost, and highly productive species for bio-energy production. However, the economic profitability and productivity of commercial reforestation with Eucalyptus for the biomass production is affected by the volume of wood produced, spatial distribution of trees and the cost of production (Danilo et al. 2018). Furthermore, producers with limited farm sizes plant Eucalyptus in high density-up to 40,000 stalks per hectare which decline its production, productivity and profitability performance (Jenbere et al. 2012; Mekonnen et al. 2007).

Given the fast expansion of Eucalyptus plantation in the highlands of Ethiopia, many of existing research works on smallholder Eucalyptus plantation especially in Amhara region are mainly focused on ecological aspects like environmental effect, hydrological effects and impacts of Eucalyptus on crop production (e.g. Fikreyesus et al. 2011; Chanie et al. 2013). However, less attention is given on the socioeconomic aspects of smallholder plantations including investigation of the factors affecting the production and commercialization of smallholder woodlots and products. Hence this study was intended to empirically answer the following two key research questions: i) what factor affect commercial value of Eucalyptus woodlot products? And ii) what are the opportunities and constraints of Eucalyptus woodlot productions in the study area?

\section{Research methods \\ Description of the study area}

The study was conducted in Wogera Districts of Amhara National Regional State of Ethiopia. The study area was selected owing to the potential for Eucalyptus woodlot production and the current fast trend of expansion and location close to urban centers where there is growing demand for wood products. Wogera is one of the administrative districts in North Gondar Zone of Ethiopia (Fig. 1) situated about $36 \mathrm{~km}$ from Gondar town and found at between $37.36{ }^{\circ} \mathrm{E}$ and $12.46^{\circ} \mathrm{N}$ longitude. The altitude of districts ranges from $1100 \mathrm{~m}$ to 3040 m.a.s.l. The annual rainfall for the Districts ranges between 1000 and $1200 \mathrm{~mm}$ and the minimum and maximum temperature is $14{ }^{\circ} \mathrm{C}$ and $33{ }^{\circ} \mathrm{C}$, respectively. The rainy months extend from June until the end of September. However, most of the persistence rainfall is received during the months of July and August (Derbe et al. 2018). According to the district agricultural office (2016) the district has total area coverage of 182,126 ha with cultivated land (46.1\%) being the dominant land use followed by, grazing land $(22.7 \%)$, forest land (11\%), building (4.42\%), rivers and gorges $(2.73 \%)$ and others $(12.85 \%)$. The total population of the District is 268,833, of which 137,057 and 131,776 were male and female, respectively. 


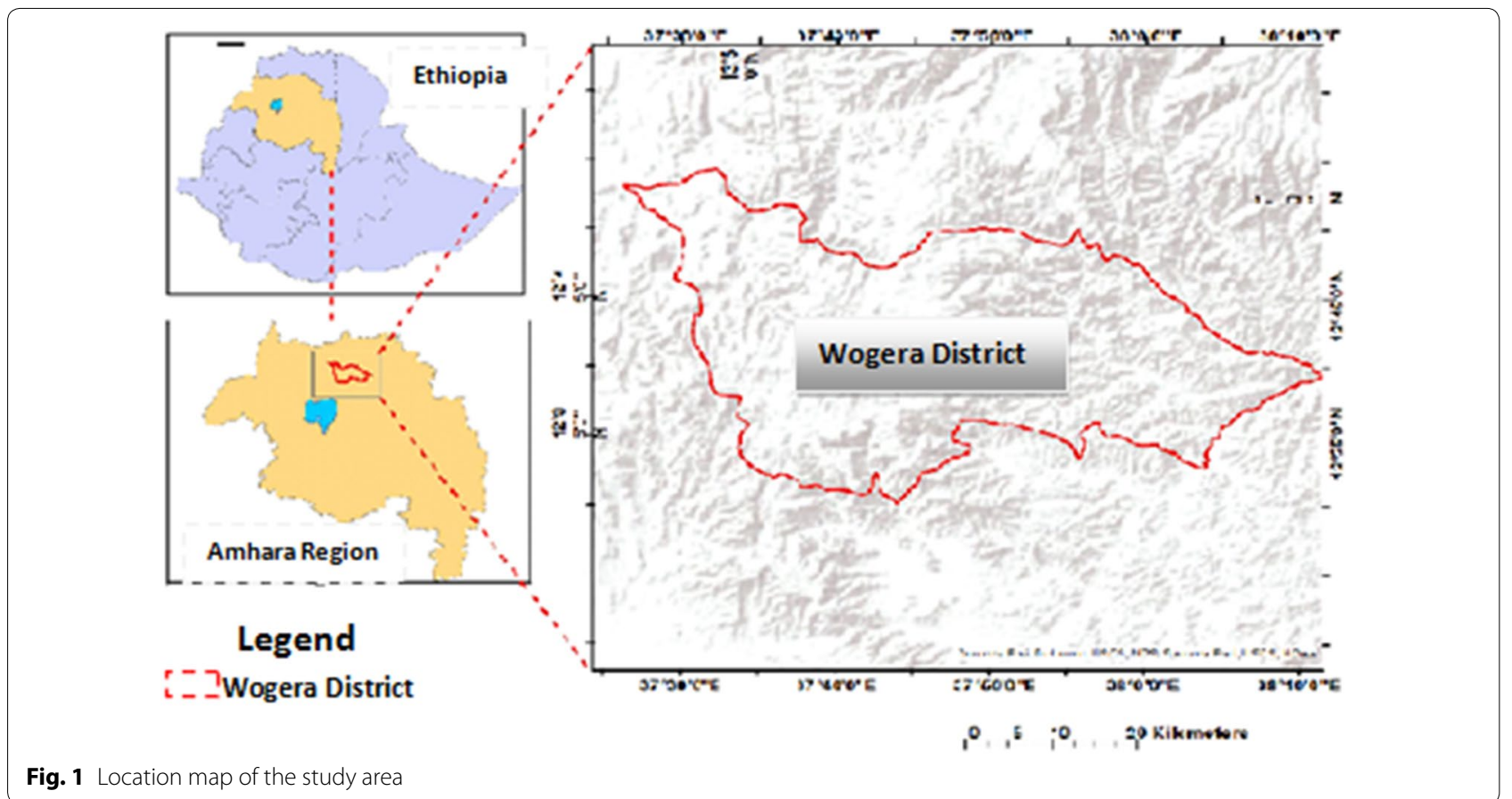

The soils types in the District have predominantly brown and black colors. The area is characterized by mixed farming system (i.e. crop and livestock production). The main crops produced in the District are wheat, barley, teff, maze, sorghum, and leguminous crops like bean, peas and lentils. Likewise, it is known by high area coverage of Eucalyptus globulus. Furthermore, the District is known by livestock production such as oxen, cows, goat, sheep, mule, horse, poultry, donkey, bull, heifer and calves (WDAO 2016).

\section{Data collection and sampling procedures}

A combination of quantitative and qualitative data was collected from both primary and secondary sources for this study. Secondary data was collected from relevant sources of published and unpublished documents to gain a general insight on the issue of enquiry. Then primary data was collected from household heads and community leaders through household interview, key informants interviews and focus group discussions. The interview schedule consists of semi-structured questions was translated to local language and pre-tested prior to the actual data collection. It includes several issues such as the socio-economic, demographic and institutional characteristics of household heads, their practices of land allocation, Eucalyptus production and marketing embodied in the household farming system. The interviews were administered with 120 randomly selected sample Eucalyptus woodlot producer household heads. As to the sampling procedures, a three stage sampling technique was used to select sample households. In the first stage Wogera District was selected purposively due to high potentials of Eucalyptus woodlot production. In the second stage, out of 41 kebeles/villages/of the District, three kebeles namely Kossoye, Ambagiorgis Zuria and Yesaq Deber were purposively selected in consultation with District Agriculture office experts due to the prevailing expansion of Eucalyptus woodlot on farm lands. In the third stage, using the Kebele inhabitants list of the sample of three kebeles using systematic random sampling techniques 120 Eucalyptus woodlot producer household heads were selected using a formula developed by Yamane (1967).

$$
n=\frac{N}{1+N\left(e^{2}\right)}
$$

where, $\mathrm{n}$ is sample size to be computed, $\mathrm{N}$ is Target population in the study area equals to 2686 and e is the level of precision. The minimum level of precision is acceptable at $10 \%$.

\section{Analytical framework}

Given the diverse data collected from the field and household heads through the combination of tools, a combination of analytical methods were used including descriptive statistics, SWOT analysis and econometrics 
model such as multiple linear regression model were used. Following the descriptive statistical analysis multiple linear regression model were run to identify significant variables determining the production and commercial value of Eucalyptus woodlot products in the study area. Multiple linear regression analysis is important for testing both economic theories and evaluating policy effects for non-experimental data because it can accommodate many explanatory variables that may be correlated (Maddala and Lahiri 1992). Unlike simple regression analysis, multiple linear regression analysis is more amenable to ceteris paribus analysis because it allows us to explicitly control many other factors which simultaneously affect the dependent variable. Greene (2003) also stated that MLR model is selected for its simplicity and practical applicability. To find out the impact of factors on commercial value Eucalyptus woodlot products in the district, the functional relationship is specified in Eq. 2 below.

$$
y=f\left(X_{1}, X_{2}, X_{3}, X_{4}, X_{5}, X_{6} \ldots X_{n}, \varepsilon_{k}\right)
$$

where, $y=$ Income (commercial value) generated from Eucalyptus woodlot products (measured in Ethiopian Birr), $\mathrm{x}_{\mathrm{n}}=$ Explanatory variables and $\varepsilon_{\mathrm{K}}=$ Stochastic error term.

The general form of the Multiple Linear Regression models for this study is expressed in Eqs. 3 and 4 below:

$$
\begin{aligned}
\mathrm{y}= & \beta_{0}+\beta_{1} \mathrm{X}_{1}+\beta_{2} \mathrm{X}_{2}+\beta_{3} \mathrm{X}_{3} \\
& +\beta_{4} \mathrm{X}_{4}+\beta_{5} \mathrm{X}_{6}+\ldots+\beta_{k} \mathrm{X}_{n}+\varepsilon_{k}
\end{aligned}
$$

where, $\mathrm{y}=$ dependent variable explained by different explanatory variable, $X_{n}=$ independent variable used to explain dependent variable, $\beta_{0}$ is intercept of regression model, $\beta_{\mathrm{k}}=$ parameters associated with explanatory variable and $\varepsilon_{\mathrm{K}}=$ Stochastic error term. This can be written as matrix notation: variables are said to be highly collinear. Mathematically it can be expressed in Eq. 5 .

$$
V I F=\frac{1}{1-R_{j}^{2}}
$$

where, $R_{j}^{2}$ is the multiple correlation coefficients between explanatory variables, the larger the value of $R_{j}^{2}$, the higher the value of VIF $\left(\mathrm{X}_{\mathrm{j}}\right)$ causing collinearity in the variable $\left(\mathrm{X}_{\mathrm{j}}\right)$. Likewise, the multicolinearity between discrete variables can be calculated using contingency coefficient. The value ranges between 0 and 1, 0 indicating no association between the variables and value close to 1 indicating a high degree of association between variables. As a rule of thumb, if the value of $C C$ is greater than 0.75 , the variables are said to be collinear. Mathematically it can be expressed in Eq. 6:

$$
C C=\sqrt{\frac{\chi^{2}}{N+\chi^{2}}}
$$

where, CC-contingency coefficient, $\chi^{2}-$ Chi square test and $\mathrm{N}-$ total sample size.

Based on existing body of knowledge through literature review the possible explanatory variables hypothesized to have an effect on the production and commercial values of Eucalyptus woodlot products were specified for the Econometrics model (Table 1).

\section{Results and discussion}

\section{Characteristics of Eucalyptus woodlot producer sampled households}

The survey result, presented in Table 2, summarizes the general characteristics of the sampled Eucalyptus producer household heads'. Most of the woodlot producers

$$
y=x \beta+\varepsilon, \quad y=\left[\begin{array}{c}
y_{1} \\
y_{2} \\
\vdots \\
y_{n}
\end{array}\right], x=\left[\begin{array}{cccc}
x_{11} & x_{12} & \cdots & x_{1 k} \\
x_{21} & x_{22} & \cdots & x_{2 k} \\
\vdots & \vdots & \vdots & \vdots \\
x_{n 1} & x_{n 2} & \cdots & x_{n k}
\end{array}\right], \beta=\left[\begin{array}{c}
\beta_{0} \\
\beta_{1} \\
\vdots \\
\beta_{k}
\end{array}\right] \text { and } \varepsilon=\left[\begin{array}{c}
\varepsilon_{1} \\
\varepsilon_{2} \\
\vdots \\
\varepsilon_{n}
\end{array}\right] \text {, }
$$

Prior to the regression analysis, multicolinearity test, heteroscedasticity diagnosis, linearity test, omitted variable and normality test were undertaken to filter the variables that are highly dependent. Gujarat (Gujarati 2004) stated that Variance Inflation Factor (VIF) is used to check multicolinearity among continuous variables. Before fitting important variables in the model it is necessary to test multicolinearity problem among continuous variables and check associations among discrete variables, because it highly affects the parameter estimates. As a rule of thumb, if the value of VIF is greater than 10 , the are male headed household headed (91.67\%) while few of them are female headed (8.33\%). Despite it doesn't give a full picture, the gender distribution can be an indication that male headed households tend to engage in Eucalyptus woodlot production than the female headed households. The mean age of the sampled producers' household heads were estimated at 52.61 years signifying the tendency of older households to engage in the production of Eucalyptus woodlots. This could probably be due to the less labour demand for Eucalyptus woodlot production as compared with the crop 
Table 1 Summary of explanatory variables used in OLS model

\begin{tabular}{lllll}
\hline Variables & Measurement & Categories of variable & Expected sign & References \\
\hline Age & Years & Continuous & $\mp$ & Khan (2012), Abiyu et al. (2012) \\
Family size & Man day equivalent & Continuous & - & $\begin{array}{c}\text { Musemwa and Mushunje (2012), Obiero (2013), } \\
\text { Namwata et al. (2012), Mekonnen (2009) }\end{array}$ \\
Land size & In ha & Continuous & + & Jenbere et al.(2012), Jiriko (2015), Tolera et al. (2008) \\
$\begin{array}{l}\text { Access to credit market } \\
\text { information }\end{array}$ & 1 if access, 0=not & Dummy & + & Minai et al. (2014), Nyagaka et al. (2010) \\
Woodlot density & 1 if access, 0=not & Dummy & + & \\
Selling Price & 1 if densely, 0 otherwise & Continuous & - & Jenbere et al. (2012) \\
Woodlot size & ETB & Continuous & + - & Muller (1974) \\
Livestock numbers & ha & Continuous & + & Mekonnen et al. (2007) Jagger et al. (2005) \\
Wealth status & 1 if rich, 0 otherwise & Continuous & - & Rehima (2006) \\
Cooperation & 1 if cooperate, $0=$ not & Dummy & + & Jenbere et al.(2012), Jiriko (2015), Vedeld et al. \\
Experience & In year & Continuous & + & Kittredge (2005) \\
\hline
\end{tabular}

Table 2 Socioeconomics and institutional characteristics

\begin{tabular}{llc}
\hline Variables & Category of variables & Mean/proportion \\
\hline Sex & Male & $110(91.67)$ \\
Marital status & Female & $10(8.33)$ \\
& Single & $3(2.5)$ \\
& Married & $106(88.33)$ \\
& Divorced & $3(2.5)$ \\
& Widowed & $8(6.67)$ \\
Education status & Literate & $68(56.67)$ \\
Wealth status & Can't read and write & $52(43.33)$ \\
& Rich & $29(24.17)$ \\
Access to market informa- & Yes & $61(50.83)$ \\
tion & Medium & $30(25)$ \\
Access to credit service & Yes & $84(70)$ \\
& No & $36(30)$ \\
Age (years) & & $87(72.50)$ \\
Woodlot size (ha) & & $33(27.5)$ \\
Experience (years) & & $52.61(14.56)$ \\
Livestock number (TLU) & & $0.26(0.19)$ \\
Total Land holding (Ha) & & $21(11.48)$ \\
Selling price of wood (ETB) & & $5.10(3.22)$ \\
Family size (MDE) & & $1.26(0.594)$ \\
\hline
\end{tabular}

Household survey data (2017); Figures in parenthesis represent \% and std. dev

production which is labour intensive and demands labour for each year of production. Similarly, married households (88.3\%) constitute the highest proportion of the Eucalyptus woodlot producer households which could be associated with the resource endowment especially land. Regarding the educational status, majority (56.67\%) of the sampled producers were literate who have formal and informal education and be able read and write. The wealth status of the households also seems to have relation with the production of Eucalyptus woodlots as it is measured by the resource endowment including land ownership. The survey result indicated that about $75 \%$ of the Eucalyptus producers' sample households are classified in the better-off $(24.17 \%)$ and medium $(50.83 \%)$ wealth classes.

The survey result also revealed that Eucalyptus woodlot has been a stable land use system practiced for many years. The mean experience of the producers' households' engagement in Eucalyptus woodlot production was 21 years implies they had good knowledge in Eucalyptus woodlot production and it has been one of the stable and main economic activity of the households. The average Eucalyptus woodlot size of the sampled households was about 0.26 ha/household which is about $20 \%$ of the average total land holding of the households. Key informants indicated that Eucalyptus is considered as a major cash crop in the study area being one of the major sources of cash income for most households.

\section{Motivation of smallholder farmers' engagement in Eucalyptus woodlot production}

Figure 2 presents the main factors that motivated the household heads to engage in Eucalyptus woodlot production in the study area. The income generation potential of woodlot production is by far the main motivating factor indicated by large proportion $(81.66 \%)$ of the producer households. They have planted Eucalyptus woodlot due to the increasing demand of Eucalyptus products and the income generation potential of the activity. It use as source of wood fuel and construction for subsistence uses; income generation to buy productive assets and 
household consumable goods and for house construction. On the other hand, about $61.66 \%$ of the respondents indicated that they converted their farmlands into Eucalyptus woodlot due to the declining in agricultural productivities meaning the land were not appropriate to produce different crops due to less fertile, swampy and water logging natures of soil. Similar results were reported by Jenbere et al. (2012) revealed that about $88 \%$ of the household heads in south central Ethiopia planted Eucalyptus trees due to its adaptability, fast growth, nonpalatability for livestock and earn high income from sale of Eucalyptus wood product (Fig. 2).

\section{Major assortments of Eucalyptus woodlot products in the study area}

Based on the size (diameter and length) classes, five common Eucalyptus woodlot products are produced and marketed in the study area. The result in Table 3 illustrated the five common assortments of Eucalyptus woodlot products identified by their local names as: poles, bigger diameter construction round wood (worage), smaller diameter construction wood (mager), Split wood and bundle of fuel wood. The different assortments of woodlot products listed in here are also preferred for different uses both in the production areas and urban centers. Pole is mostly used for electricity transmission pole and characterized by their larger diameter $(15-17.5 \mathrm{~cm})$, straightness and length $(6-8 \mathrm{~m})$. Construction wood is classified locally into Worage and Mager depending on the diameter of the round woods used for construction purposes. Worage is mainly used for house construction, particularly at roof parts of house and its diameter and length ranges from $10-12 \mathrm{~cm}$ to $8-10 \mathrm{~m}$, respectively. While Mager is also used for house construction in horizontal position and its diameter and length ranges from $8-10 \mathrm{~cm}$ to $6-8 \mathrm{~m}$, respectively. Split wood is the other most important types of product, which mainly used for house construction at vertical positions in all rounds and its length ranges 4-6 $\mathrm{m}$.

The selling price of the local assortments of the Eucalyptus woodlot products also varies according to their diameter and length. Table 3 presents the average selling prices of the local Eucalyptus woodlot products in the study area. Larger diameter products such as Poles and Worage fetches higher prices, $50 \mathrm{ETB} /$ piece and $33 \mathrm{ETB} /$ piece, respectively. While smaller diameter assortments such as Mager (30 ETB/piece), bundle of fuel wood (17 ETB/bundle) and Split wood (13 ETB/piece) fetches lower prices (Table 3).

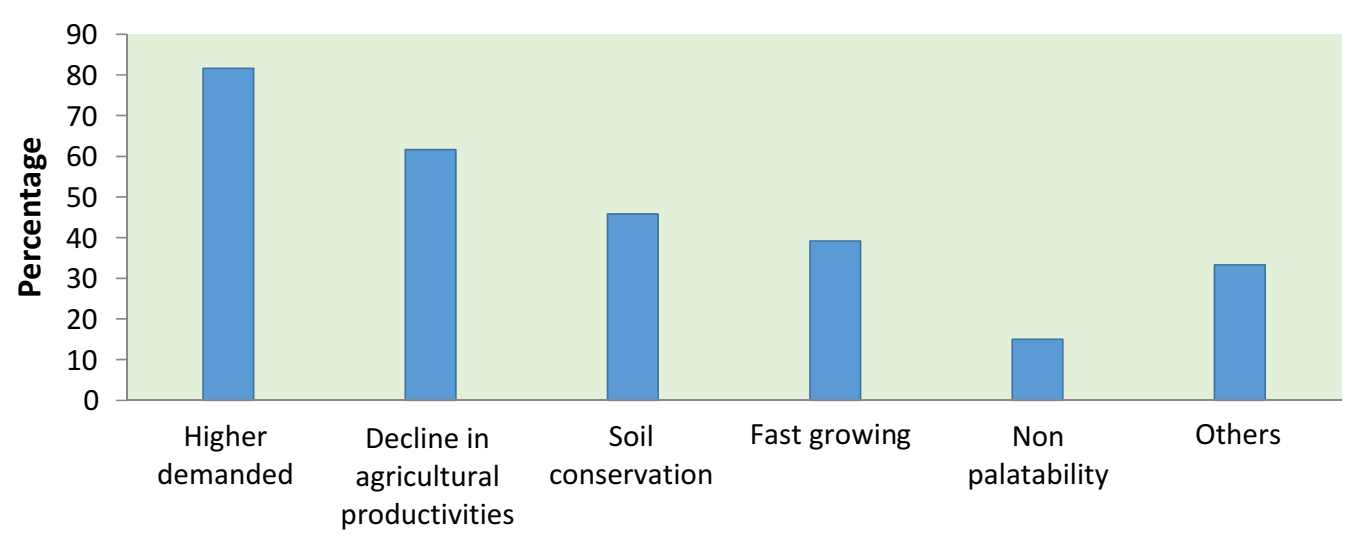

Fig. 2 Factors that motivate farmers to start Eucalyptus wood lot production (*Multiple responses)

Table 3 Size classes of local Eucalyptus product assortments

\begin{tabular}{llll}
\hline Local Eucalyptus woodlot products & Diameter $(\mathbf{c m})$ & Length $(\mathbf{m})$ & $\begin{array}{l}\text { Average selling price } \\
\text { per product in ETB/ } \\
\text { piece }\end{array}$ \\
\hline Pole for electricity & & & 50 \\
Poles for roof (Worage) & $15-17.5$ & $6-8$ & 33 \\
Poles for wall (Mager) & $10-12$ & $8-10$ & 30 \\
Bundle of fuel wood & $8-10$ & $6-8$ & 17 \\
Split wood & - & $4-6$ & 13 \\
\hline
\end{tabular}




\section{Factors influencing the commercial value of Eucalyptus Woodlot Products}

The multiple linear regression model result presented in Table 4 indicates the significant factors influencing the commercial value of Eucalyptus woodlot production in the study area. The model was significant $(P=0.0000)$ with higher value of $R^{2}(0.6244)$ indicating larger proportion of the variation in the commercial value of the woodlot products is explained by the explanatory variables used in the model. Similarly, the regression model was adequate since in determining model adequacy features such as the $\mathrm{R}^{2}$ and the F-value are observed (Gujarati 2007). Of the 14 variables included in the model five variables namely age of the household heads $(P=0.092)$, experience of household heads $(\mathrm{P}=0.026)$, access of credit service $(P=0.018)$, wealth status of household heads $(\mathrm{P}=0.084)$ and woodlot size $(\mathrm{P}=0.000)$ were found to be significant factors influencing the commercial value of Eucalyptus woodlot products. Regarding the relationship of variables with commercial value of woodlot products the variables: household head age, wealth status and woodlot size of household heads had positive relationship. While access of credit service and experience of household heads had negative relationship (Table 4).

Age of the household head was significant at 10\% probability level with positive sign indicating that an increase in each unit of household age will have an increase in the commercial value gained from woodlot products. The possible explanation for this result could be the tendency of older aged household heads engagement in eucalyptus woodlot production due to the less labour intensive nature of the business. Other probable reason could be resource endowment such as land and the associated woodlot ownership of older household heads. Older household heads tend to have not enough labors for labour intensive businesses such as produce agricultural crops (cereals). Consequently, older household heads have higher tendency of allocating farm lands for woodlot production due its less labour intensive and less costly to produce than crop production. The present result is in line with Cavendish (2000) and Coulibaly-Lingani et al. (2009) that indicated older households have difficulty to performing laborious agricultural tasks and may turn to resource collection activities that demand less physical labor, such as harvesting and providing of income from Non Timber Forest Products (NTFPs).

Experience of the household heads in woodlot production was also among the highly significant factor. However, the relation was found to be negative. Meaning households with longer experience in Eucalyptus woodlot production receive lower commercial incomes from their woodlots. The possible explanation for this could be the old age of the coppice stands which may affect

Table 4 OLS model result of determinants of commercial value of woodlot products

\begin{tabular}{|c|c|c|c|c|}
\hline \multirow[t]{2}{*}{ Variables } & \multicolumn{4}{|l|}{ Robust } \\
\hline & Coef. & Std. err. & t-ratio & $p$ value \\
\hline Age of $\mathrm{HH}$ in years & 576.117 & 338.374 & 1.70 & $0.092^{*}$ \\
\hline Livestock number in TLU & 2400.051 & 2436.159 & 0.99 & 0.327 \\
\hline Land size of $\mathrm{HH}$ in ha & -5908.873 & 4517.383 & 1.14 & 0.257 \\
\hline Family size in adult equivalent & 8910.597 & 7825.737 & 1.14 & 0.257 \\
\hline Experience of $\mathrm{HH}$ in Eucalyptus production (years) & -1084.858 & 481.246 & -2.25 & $0.026^{* *}$ \\
\hline Wealth status of $\mathrm{HH}$ (1 = poor, 0 otherwise) & -3316.951 & 9055.956 & -0.37 & 0.715 \\
\hline Wealth status of $\mathrm{HH}$ (1 = rich, 0 otherwise) & $21,597.51$ & $12,392.01$ & 1.74 & $0.084^{*}$ \\
\hline Woodlot size in ha & $62,814.91$ & $12,208.6$ & 5.15 & $0.000^{* * *}$ \\
\hline Selling price of woodlot product in ETB & 256.949 & 595.3887 & 0.43 & 0.667 \\
\hline Contract with traders $(1=$ have, 0 otherwise & -9557.608 & 7153.563 & -1.34 & 0.184 \\
\hline Access of credit service ( $1=$ access, 0 otherwise) & $-22,367.07$ & 9290.448 & -2.41 & $0.018^{* *}$ \\
\hline Woodlot density ( 1 = dense, 0 otherwise) & 8410.302 & 6905.495 & 1.22 & 0.226 \\
\hline Cooperation participation decision ( 1 = cooperate, 0 not $)$ & 2113.034 & 8754.79 & 0.24 & 0.810 \\
\hline Access of market information ( $1=$ access, 0 otherwise) & 209.522 & 7751.227 & 0.03 & 0.978 \\
\hline Constant term & $-260,069.8$ & $66,089.25$ & -3.94 & $0.000^{* * *}$ \\
\hline $\begin{array}{l}\text { Number of obs. }=120 ; F(14,105)=6.22 ; \\
\text { Prob }>F(P=0.0000) \\
\text { R-squared }=0.6244\end{array}$ & & & & \\
\hline
\end{tabular}

Dependent variable is commercial value of Eucalyptus woodlot products measured in ETB *** ** and * shows the value statistically significant at $1 \%, 5 \%$ and $10 \%$ level, respectively 
the products quality. As the age of the coppice rounds increased, the coppicing ability and coppics stands product quality declined. Similar results were also reported by Obiero (2013) who reported a negative relationship between the farmers' experience and farm yield.

The relation between the variables woodlot size and commercial value gained from Eucalyptus woodlot products was significant and positive. The explanation for this result is straight forward as the woodlot size increases the amount of production also increase and so also the commercial value gained from woodlots. The implication is that household heads with large woodlot, produce and sell large amounts of Eucalyptus woodlot products to generate high level of income. This result is consistent with Gebreegziabher et al.(2010) revealed that land size has significant and positive effect on tree planting decision and production. This implies household heads with large land size would increase the propensity to plant tree and the quantity of trees planted. Likewise, Jagger et al. (2005) also reported that farm woodlots contribute positively to the income and resilience of rural households. Moreover, Gizachew (2017) and Derbe et al. (2018) revealed that total land holding of the household heads had significant positive effects on the household's decision to produce and establish Eucalypts woodlot on the farm lands.

Wealth status and access to credit were among the significant variables but with positive and negative effects on the commercial value of woodlots, respectively. The positive effect associated with the variable wealth status can probably be due to the tendency of better-off households to establish wider areas of woodlots and their less urgency to harvest their woodlots. As a result with enough waiting time they tend to produce larger size assortments which fetches better prices at markets (Table 3). The implication was household heads' with better economic status compared to others in the study area planted large size of land by Eucalyptus for land tenure security purpose; purchase additional woodlot land; hired more labor force to plant, hoe, weed, cut and transport woodlot product effectively in turn increase the return or commercial value of woodlot products. Poor households on the other hand tend to enter in interlocked transactions by receiving advance payments and early harvesting of their woodlots producing lower diameter products receiving lesser prices. Access of credit service was statistically significant but with negative effect. This could result them to rush to harvest their woodlots at early stage for loan repayment. It can also be inferred that, though household heads obtained credit service, they did not use the credit properly for Eucalyptus woodlot production purpose rather used for other trading activities and purchasing of consumable goods and services. Similar study by Jiriko (2015) also indicate that wealth status of respondents were positively and significantly affect agricultural production. Similarly, Kamanga et al. (2009) affirmed that poor households have the lowest source of total on farm forest income than wealthier due to little access to agricultural land. Jenbere et al. (2012) also revealed that wealth status of the households significantly affected land area allocated to Eucalyptus plantations in south central Ethiopia. Moreover, this study is consistent with the previous studies, which stated that tree planting in East Africa increases with wealth, tenure security and pressure on forest resources (Ndayambaje et al. 2012; Kakuru et al. 2014). Furthermore, Nguyen (2005) confirmed that household heads' wealth status was found to influence timber harvesting positively because rich household could have accessed technology, capital and labor.

\section{Problems and Opportunities of Eucalyptus woodlot Production in the study area}

Even though empirical results pointed out that variables which were included in the models above affected the commercial value of Eucalyptus woodlot products, households perceived a number of other constraints and opportunities that affected woodlot production in their area. As a result, they have given their perspectives on most important constraints and opportunities affecting Eucalyptus woodlot production and their responses are summarized below (Table 5). Like researchers, there is also still argument among household heads regarding to the plantation and production of Eucalyptus woodlot in the study area. Some of them support and the other totally opposed. Those household heads who were support an expansion of Eucalyptus stated that it is an essential plant which help to improve our livelihood by earning high income; serve as collateral; unlike other crops it needs less inputs to produce meaning with least cost input possible to maximize levels of profit; it used for building construction and security; helps to work together in turn improves social capital or interaction among household heads; easy to adapt difficult environmental conditions; and helps to balance the environments. On the other hand, those who were not support Eucalyptus plantation stated that household heads and concerned stakeholders should have control the expansion of Eucalyptus woodlot production due to its negative (acidity) effect on soil and water, shading and allelolphatic effect on other crops, its cross boundary effect on neighbors' crops.

\section{Conclusion and recommendations}

In the study area, there is a prevailing expansion of Eucalyptus woodlot production on crop land of farmers perhaps due to the attractive financial income gained 
Table 5 SWOT analysis matrix of woodlot production

\begin{tabular}{|c|c|}
\hline $\begin{array}{l}\text { Strength on Eucalyptus woodlot } \\
\text { production }\end{array}$ & $\begin{array}{l}\text { Weakness on Eucalyptus woodlot } \\
\text { production }\end{array}$ \\
\hline Provides high cash income & $\begin{array}{l}\text { Allelolphatic effect on soil and } \\
\text { crops }\end{array}$ \\
\hline Adapt on infertile land & Cause for water shortage \\
\hline Fast growing and high coppices & $\begin{array}{l}\text { Create conflicts between crop and } \\
\text { eucalyptus producers }\end{array}$ \\
\hline Non-palatability natures & Easily attack by thieves \\
\hline \multicolumn{2}{|l|}{ Less labor intensive to crop } \\
\hline Opportunities on production & Threats on production \\
\hline Multipurpose & Prevalence of theft \\
\hline Good infrastructure & $\begin{array}{l}\text { Loss of crop land and domestic } \\
\text { animals }\end{array}$ \\
\hline Too little attack by wild animals & They will become net buyers \\
\hline Unproductive land expansion & Absence of cluster planting \\
\hline
\end{tabular}

from woodlot production than agricultural crop production. However, like economist and environmentalist there is still wide divergent opinion among farmers regarding on the benefits and side effects of Eucalyptus woodlot plantation and production in the study area. The result of multiple linear regression model also indicated that policy relevant variables have greatest influence on commercial value of Eucalyptus woodlot production system. It revealed that age of household heads had significant and positive effect on commercial value of woodlot products since older household heads had not active labour to produce agricultural crops (cereals) than to woodlot production. Similarly, woodlot size had a positive and significant effect on commercial value of woodlot products since large woodlot helps for household heads to produce and sell large amounts of Eucalyptus woodlot product. Moreover, wealth status of household heads founded to have significant and positive effect on commercial value of Eucalyptus woodlot production since household heads' with better economic status compared to others in the study area planted large size of Eucalyptus either for consumption and commercialization purpose or land tenure security purpose. While, access of credit service and experience had a significant and negative effect on commercial value of woodlot products which infers though household heads who obtained credit service, did not use the credit properly for woodlot production purpose rather used for purchasing of consumable goods and services. At the same time, experienced household heads' knows the side effect of Eucalyptus woodlot production on soil, water, neighbors and crops very well than less experienced. Hence they were probably focused on crop and animal production than Eucalyptus woodlot production in the study area.
Given the potential of the District on Eucalyptus woodlot production and its significant role to improve the livelihood of most smallholder farmers, traders and consumers, the following implication has given for the development of Eucalyptus woodlot production in the study area. Credit service is one of the most important resources in agricultural production. The study recommends that for holistic woodlot production among household heads, proper use of credit service is necessary. Hence, concerned stakeholders should create awareness to household heads regarding to the utilization of credit service for Eucalyptus woodlot production through avenue like mass media, extension agents and other means of capacity building. Likewise, to promote woodlots with sustainable management and high value like planting and producing more, credit institutions could provide special loans for smallholder farmers who would like to convert their woodlots. Moreover, the respective stakeholders should provide better farm land and woodlot/coppices/management practice to increase production and commercial value of Eucalyptus woodlot products. Furthermore, to reduce the tension between Eucalyptus woodlot producers and crop producers' cluster planting is advisable.

\section{Abbreviations \\ FAO: Food and Agricultural Organization; e: error; ETB: Ethiopian Birr; $\mathrm{HH}$ : household head; TLU: Tropical Livestock Unit; NTFPs: Non Timber Forest Products; JFD: Joint Forest Development; m.a.s.l: meter above sea level; SWOT: strength weakness opportunity and threat; OLS: ordinary least square; VIF: Variance Inflation Factor; CC: contingency coefficient; WDAO: Wogera District Agricultural Office.}

\section{Authors' contributions}

$A B D$ and $A A A$ designed and performed the surveys, analyzed the data, wrote, review and edit the manuscript. AAA and ADK designed the research, review, editing and revised the manuscript. All authors read and approved the final manuscript.

\section{Author details \\ ${ }^{1}$ Department of Agricultural Economics, College of Agriculture and Rural Transformation, University of Gondar, P.O. Box 196, Gondar, Ethiopia. ${ }^{2}$ Depart- ment of General Forestry, College of Agriculture and Rural Transformation, University of Gondar, Gondar, Ethiopia.}

\section{Acknowledgements}

The author would like to thank the University of Gondar and CHAINS project for the financial support for this research and was obtained from "CHAnces IN Sustainability: promoting natural resource based product chains in East Africa (CHAINS) project funded by the German Federal Ministry of Education and Research and organized by Technische Universitat Dresden and University of Gondar. Moreover, we thank the respondents and district experts for their provision of information for the study.

\section{Competing interests}

The authors declare that they have no competing interests.

\section{Availability of data and materials}

The author wants to declare that they can submit the data at any time based on publisher's request. The datasets used and/or analyzed during the current study will be available from the author on reasonable request. 


\section{Consent for publication}

The authors have agreed to submit for Environmental Systems Research journal and approved the manuscript for submission.

\section{Ethics approval and consent to participate}

Ethical clearance letters were collected from University of Gondar research and community service directorate and North Gondar Zone administrative office to care for both the study participants and the researchers. During survey, official letters were written for the district and kebeles/villages/informed verbal consent was obtained from each client, and confidentiality was maintained by giving codes for each respondent rather than recording their name. Study participants were informed that clients have a full right to discontinue or refuse to participate in the study. Hence, all participants throughout the research, including survey households, enumerators, the supervisors and key informants were fully informed of the objectives of the study. They were approached friendly in free moods until the end of this research.

\section{Funding}

This study was financially supported by CHAINS project funded by the German Federal Ministry of Education and Research organized by Technische Universitat Dresden and University of Gondar.

\section{Publisher's Note}

Springer Nature remains neutral with regard to jurisdictional claims in published maps and institutional affiliations.

Received: 9 November 2018 Accepted: 11 February 2019 Published online: 21 February 2019

\section{References}

Abiyu A, Shete M, Gratzer G (2012) Spatial patterns and determinants of smallholder tree planting in Northwest Highlands of Ethiopia. JAD 2(2):25

Alemu A, Pretzsch J, Secco L, \& Elshikh T (2014) Contribution of small-scale gum and resin commercialization to local livelihood and rural economic development in the drylands of Eastern Africa. Forests, 5(ISSN 1999-4907): pp 952-977

Cavendish W (2000) Empirical regularities in the poverty-environment relationship of rural households: evidence from Zimbabwe. World Dev 28(11):1979-2003

Chanie T, Collick AS, Adgo E, Lehmann CJ, Steenhuis TS (2013) Eco-hydrological impacts of Eucalyptus in the semi humid Ethiopian Highlands: the Lake Tana Plain. J Hydrol Hydromech 61(1):21-29b

Coulibaly-Lingani P, Tigabu M, Savadogo P, Oden PC, Ouadba JM (2009) Determinants of access to forest products in southern Burkina Faso. For Pol Econ 11(7):516-524

Derbe T, Yehuala S, Agitew G (2018) Factors influencing smallholder farmers adoption of eucalyptus woodlot in Wogera District, North Gondar Zone Amhara Regional State of Ethiopia. Int J Sci Res Manag 6(07):566-574. https://doi.org/10.18535/ijsrm/v6i7.em07

Fikreyesus S, Kebebew Z, Nebiyu A, Zeleke N, Bogale S (2011) Allelopathic effects of Eucalyptus camaldulensis Dehnh on germination and growth of tomato. Am-Eurasian J Agric Environ Sci 11(5):600-608

Gebreegziabher Z, Mekonnen A, Kassie M, Köhlin G (2010) Household tree planting in Tigrai. Tree species, purposes, and determinants, Northern Ethiopia

Gizachew K (2017) Expansion of eucalypt woodlot and its factors in Cheha District, Southern Ethiopia. World Sci News 66:163-180

Greene W (2003) Econometric analysis. Pearson Education Inc., Upper Saddle River

Gujarati, D. 2004. Basic Econometrics. United States Military Academy, West Point. Tata McGraw-Hil

Gujarati DN (2007) Essentials of econometrics. New Delhi, Mc-Graw-Hill

Jagger P, Pender J, Gebremedhin B (2005) Trading off environmental sustainability for empowerment and income: woodlot devolution in northern Ethiopia. World Dev 33(9):1491-1510

Jenbere D, Lemenih M, Kassa H (2012) Expansion of eucalypt farm forestry and its determinants in Arsi Negelle District, South Central Ethiopia. Small Scale For 11(3):389-405
Jiriko RK (2015) Socio-economic factors affecting the performance of women in food production. Global J Agr Res. 3(2):37-45

Kakuru OV, Doreen M, Wilson M (2014) Adoption of on-farm tree planting in Kibaale District, Western Uganda. J Sustain For. 33(1):87-98

Kamanga P, Vedeld P, Sjaastad E (2009) Forest incomes and rural livelihoods in Chiradzulu District, Malawi. Ecol Econ 68(3):613-624

Kebebew Z, Ayele G (2010) Profitablity and household income contribution of growing Eucalyptus globules(Labill) to smallholder farmers: the case of central highland of Oromia, Ethiopia. Eur J For. 2(1):25-29

Khan H (2012) Measurement of technical, allocative and economic efficiency of tomato farms in northern Pakistan. J Agr Sci Technol. 2(10B):1080

Kittredge DB (2005) The cooperation of private forest owners on scales larger than one individual property: international examples and potential application in the United States. For Pol Econ 7(4):671-688

Lemeneh M, Kassa H (2014) Re-greening Ethiopia: history, challenges and lessons. Forests 5:1896-1909

Maddala GS, Lahiri K (1992) Introduction to econometrics, vol 2. Macmillan, New York

Mekonnen A (2009) Tenure security, resource endowments, and tree growing: evidence from the Amhara region of Ethiopia. Land Econ 85(2):292-307

Mekonnen Z, Kassa H, Lemenh M, Campbell B (2007) The role and management of eucalyptus in Lode Hetosa district, Central Ethiopia. For Trees Livelihoods 17(4):309-323

Minai JM, Nyairo N, Mbataru P (2014) Analysis of socio-economic factors affecting the coffee yields of smallholder farmers in Kirinyaga County, Kenya. J Agr Crop Res 2(12):228-235

Muller J (1974) On sources of measured technical efficiency: the impact of information. Am J Agr Econ 56(4):730-738

Musemwa L, Mushunje A (2012) Factors affecting yields of field crops and land utilisation amongst land reform beneficiaries of Mashonaland Central Province in Zimbabwe. J Dev Agr Econ 4(4):109-118

Namwata BM, Masanyiwa ZS, Mzirai OB (2012) Productivity of the agroforestry systems and its contribution to household income among farmers in Lushoto District, Tanzania. Int J Phys Soc Sci 2(7):369-392

Ndayambaje JD, Heijman WJM, Mohren GMJ (2012) Household determinants of tree planting on farms in rural Rwanda. Small Scale For. 11(4):477-508

Nguyen TQ (2005) What benefits and for whom. Eff Devol For

Nyagaka DO, Obare GA, Omiti JM, Nguyo W (2010) Technical efficiency in resource use: evidence from smallholder Irish potato farmers in Nyandarua North District, Kenya. Afr J Agric Res 5(11):1179-1186

Obiero EO (2013) Social economic factors affecting farm yield in Siaya District, Siaya County, Kenya (Doctoral dissertation)

Oduol J, Nang'ole E (2012) Economic and market assessment of agroforestry options in Ethiopia

Raphael B, Alemu A (2016) Evaluation of the current construction wood and fuel wood value chains from Amhara region, Ethiopia. GIZ Technical Report. Forest and Biodiversity Program, Addis Ababa

Rehima M (2006) Analysis of Red pepper marketing: the case of Alaba and Silte in SNNPRS (Doctoral dissertation, MSc thesis presented to the school of graduate studies of Haramaya University, Ethiopia)

Simões D, Dinardi A, da Silva M (2018) Investment uncertainty analysis in Eucalyptus bole biomass production in Brazil. Forests 9(7):384. https://doi. org/10.3390/f9070384

Tadesse W, Gezahegne A, Tesema T, Shibabaw B, Tefera B, Kassa H (2015) Enhancing the role of forestry in building climate resilient green economy in Ethiopia. Strategy for scaling up effective forest management practices in Amahara regional state with particular emphasis on smallholder plantations. CIFOR, Addis Ababa

Tolera M, Asfaw Z, Lemenih M, Karltun E (2008) Woody species diversity in a changing landscape in the south-central highlands of Ethiopia. Agr Ecosyst Environ 128(1):52-58

Vedeld P, Angelsen A, Bojö J, Sjaastad E, Berg GK (2007) Forest environmental incomes and the rural poor. Forest Policy and Economics 9(7):869-879

WDAO (2016) Wogera District Agricultural Office. Unpublished report

Yemane M (1967) Elemantary sampling theory. Printice-Hall Inc., Englewood Cliffs

Yitaferu B, Abewa A, Amare T (2013). Expansion of Eucalyptus woodlots in the fertile soils of the highlands of Ethiopia. Could it be a treat $n$ future cropland use?

Zerga B, Berta A (2016) Preference, purpose, and pattern of Eucalyptus tree farming in Eza Wereda, Ethiopia 